\title{
Cloning, characterization and in vitro and in planta expression of a glucanase inhibitor protein (GIP) of Phytophthora cinnamomi
}

\author{
Ivone M. Martins • Fátima Martins • \\ Hélio Belo • Madalena Vaz • Marisa Carvalho • \\ Alfredo Cravador • Altino Choupina
}

Received: 20 March 2013/Accepted: 4 January 2014

(C) Springer Science+Business Media Dordrecht 2014

\begin{abstract}
Oomycetes from the genus Phytophthora are fungus-like plant pathogens that are devastating for agriculture and natural ecosystems. They are able to secrete a glucanase inhibitor protein (GIP) that inhibits the activity of endoglucanases (EGases) involved in defense responses against infection. One of the most widely distributed and aggressive Phytophthora species, with more than 1,000 host plants is $P$. cinnamomi. In this work we report the sequencing and characterization of a class of GIPs secreted by Phytophthora cinnamomi. The gip gene from $P$. cinnamomi has a $937 \mathrm{bp}$ ORF encoding a putative peptide of 312 deduced amino acids. The expression of this gene was studied during growth in different carbon sources (glucose, cellulose and sawdust), by RT-qPCR and its level of expression was evaluated at five time points. The highest expression of gip gene occurred in sawdust at $8 \mathrm{~h}$ of induction. In vivo infection of $C$. sativa revealed an increase in gip expression from 12 to $24 \mathrm{~h}$. At $36 \mathrm{~h}$ its expression decreased suggesting that a compensatory mechanism must occur in plant.
\end{abstract}

Keywords Castanea sativa · GIP · HE-TAIL PCR · Phytophthora cinnamomi $\cdot$ RT-qPCR

I. M. Martins · F. Martins · H. Belo $\cdot$ M. Vaz $\cdot$ M. Carvalho

A. Choupina $(\square)$

CIMO, Escola Superior Agrária de Bragança, Instituto

Politécnico de Bragança, Campus de Santa Apolónia,

Apartado 1172, 5301-855 Bragança, Portugal

e-mail: albracho@ipb.pt

A. Cravador

IBB/CGB, Universidade do Algarve, Campus de Gambelas,

8005-139 Faro, Portugal

\section{Introduction}

The class oomycetes or "water moulds" form one of several lineages within the Kingdom Chromista that independently evolved to a parasitic lifestyle and consequently are thought to have developed alternative mechanisms of pathogenicity. Oomycetes share with many bacterial, fungal and nematode plant pathogens the requirement for living host tissue for at least part of the infection cycle. To establish infection, these pathogens must evade, suppress or manipulate host defenses. Due to their particular physiological characteristics, no efficient treatments against diseases caused by these microorganisms are presently available. To develop such treatments, namely against Phytophthora, it appears essential to dissect the molecular mechanisms that determine the interaction between Phytophthora species and host plants.

Phytophthora cinnamomi Rands is a destructive, widespread soil-borne pseudofungus belonging to the class oomycetes that infects many plant hosts including forest, ornamental and fruit species. It has been often associated with the decline of forest species, as well as other woody perennial plant species [1]. For instance, the ink disease of Castanea sativa Mill, one of the most destructive diseases in $C$. sativa is caused by this oomycete. The most common symptoms are root necrosis and reduction in root growth, which invariably lead to the trees death [2].

Phytophthora cinnamomi, whose life cycle develops integrally in the soil, requires moist soil conditions and warm temperatures to be active, but visible damage caused by the disease most often occurs in summer when plants are drought stressed. This pathogen can grow saprophytically in the soil and persists in soil or infected plant material as chlamydospores and, to a lesser extent, as oospores. It is known to survive for as long as 6 years in 
moist soil, and it is clear that moisture is a key factor in the establishment, spread and longevity of this pathogen [3].

Identification and diagnostic techniques for $P$. cinnamomi require expert attention. Preventative measures and chemical application are the typical forms of control for this pathogen [4]. By the moment there are no eradication methods available.

Several key cellular events, such as adhesion to the host surface, penetration, and colonization of host tissue, take place during plant infection by oomycetes that can also manipulate biochemical and physiological processes in their host plants through a diverse array of virulence or avirulence molecules, known as effectors [5-8]. In susceptible plants, these effectors promote infection by suppressing defense responses, enhancing susceptibility, or inducing disease symptoms. Alternatively, in resistant plants, effectors are recognized by the products of plant resistance genes, resulting in host cell death and effective defense response known as the hypersensitive response (HR) restricting the pathogen to an area of scorched earth [7, 9]. Phytophthora effectors that suppress host defense responses have been described in several pathosystems [10-12]. Suppression of host defenses can occur through the production of inhibitor proteins that target host enzymes [13].

Early observations that plants secrete inhibitor proteins that bind and inactive microbial hydrolases, specifically the binding of plant polygalacturonase inhibitor proteins (PGIPs) to fungal polygalacturonases, spurred the search for analogous inhibitor proteins from microbes that might inactivate the $\beta(1,3)$ endoglucanases or chitinases of the plant host [14]. Glucanase inhibitor protein (GIP), is thought to function as counter defensive molecule that inhibits the degradation of $\beta(1,3)$ and $\beta(1,6)$ glucans in the pathogen cell wall and/or the release of defense-eliciting oligosaccharides by host $\beta(1,3)$ endoglucanases [9].

Pathogens secrete endo $\beta(1,4)$ glucanases, which hydrolyze a range of plant cell wall glucans, while the host counters by synthesizing endo $\beta(1,3)$ glucanase that specifically degrade the hyphal wall $\beta(1,3), \beta(1,6)$ glucans, rendering the pathogen susceptible to cell lysis. The $\beta(1,3)$, $\beta(1,6)$ glucan elicitors that are released during this process are perceived by the plant, by a presumed plasma membrane-bound receptor, and a signaling cascade is initiated, resulting in the up-regulation of a number of plant defenses.

Since the recent identification of GIPs, studies have focused on their biochemical characterization, addressing features such as binding properties and ligand specificity. The observation that these proteins bind strongly to enzymes that degrade cell wall polysaccharides, together with various sets of expression data, suggests that they are likely to influence plant-pathogen interactions. However, their biological significance has not yet been established. Many questions also remain at the molecular level, such as the identity of the domains and key residues of the inhibitor proteins that contribute to the recognition specificity and high avidity binding.

The objective of the present work was to clone and characterize a gene from $P$. cinnamomi homologous to gip genes, and analyze their expression when this species grows in cultures whit different carbon sources and during host plant infection.

\section{Materials and methods}

Biological material

Isolate Pr120 of P. cinnamomi was kindly provided by Eugénia Gouveia from Instituto Politécnico de Bragança. It was isolated from soil samples associated with a $C$. sativa tree affected by the ink disease in Trás-os-Montes region (northeast Portugal). The strain was grown in the dark for 4-6 days at $22-25^{\circ} \mathrm{C}$ in PDA (Potato-Dextrose Agar) medium.

Total genomic DNA from $P$. cinnamomi mycelium was obtained as described in [15].

C. sativa chestnuts were surface sterilized, germinated in sterile vermiculite and grown in a greenhouse until their root length reached $5-6 \mathrm{~cm}$.

\section{Plasmids}

pET-28a(+) (Novagen), is a 5369 bp Escherichia coli expression vector containing the kanamicyn resistance gene. It is regulated by the T7 promoter (present as a $16 \mathrm{bp}$ fragment) and by the $\mathrm{T} 7$ terminator (present as a $46 \mathrm{bp}$ ).

pIM3.1, a $6.3 \mathrm{~kb}$ construct [based on pET28a(+)], contains an expression cassette consisting of the GIP gene (gip), present as a 937 bp SacI-HindIII fragment. This was obtained by polymerase chain reaction (PCR) amplification of a $937 \mathrm{bp}$ ORF of gip from P. cinnamomi strain 120 DNA, using as primers SacGIP (5'-GAG CTC GAC ATG TTT ACT TCC GG, insertion of restriction site SacI in bold) and HindGIP (5'-CCA AGC TTG TCC TTA TGC CTT GAT G, insertion of restriction point HindIII in bold), digesting this fragment with SacI-HindIII and finally cloning it into SacI-HindIII digested pET-28a(+). The DNA digested vector band was purified in a low melting point (LMP) agarose gel and Wizard ${ }^{\circledR} \mathrm{SV}$ Gel and PCR Clean-Up System (Promega), following the manufacturer's instructions. Correctly oriented clones were selected by restriction analysis with $X h o I$. The positive clone obtained was sequenced to confirm the correct integration of the insert. The sequencing of the fragments of the DNA 
obtained was carried through in an automatic sequencer ABI Prism 377TM from Applied Biosciences (Foster City, CA, USA).

Amplification of a short fragment of the gip gene

A PCR was used to amplify a $308 \mathrm{bp}$ fragment of the gip gene. Degenerate oligonucleotide primers M1 (5'-GAG AAG CCC AGC AAG TTC SCC) and M3 (5'-GCS GAC ACG CGM GMG TAC ACA) were designed based on gip, sequences alignment from $P$. sojae and $P$. infestans [14]. The PCR cycling conditions were $94{ }^{\circ} \mathrm{C} / 5 \mathrm{~min}$, followed by 36 cycles of $94{ }^{\circ} \mathrm{C} / 1 \mathrm{~min} ; 63{ }^{\circ} \mathrm{C} / 1 \mathrm{~min} ; 72{ }^{\circ} \mathrm{C} / 30 \mathrm{~s}$, and ending with $72{ }^{\circ} \mathrm{C} / 5 \mathrm{~min}$. Each $50 \mu \mathrm{l} \mathrm{PCR}$ contained $0.8 \mathrm{mM}$ dNTP, $0.2 \mathrm{mM}$ of each primer, $100 \mathrm{ng}$ genomic DNA, and $1 \mathrm{U}$ Taq DNA polymerase in the appropriate buffer. Aliquots of the PCR reactions were separated on $0.8 \% \mathrm{w} / \mathrm{v}$ agarose gel electrophoresis and stained with ethidium bromide, to check for the presence of the expected amplicon.

Amplification of unknown genomic DNA sequence of gip

The high-efficiency thermal asymmetric interlaced-PCR (HE-TAIL PCR) is an efficient method to amplify unknown genomic DNA sequences adjacent to short known regions by flanking the known sequence with asymmetric PCR. In this procedure gene-specific primers M1, M3, M2 (5'-GCC GTT YTC CTT GAT CAG CGG), S1 (5'-AGG CGT TGT CGC CCC AGA CC), S2 (5'-CGG CCG CGG TGA CGC TGA CG) and S4 (5'-GGT CTG GGG CGA CAA CGC CT) were used. Degenerated primers R1 (5'-NGT CGA SWG ANA WGA A), R2 (5'GTN CGA SWC ANA WGT T), R3 (5'-WGT GNA GWA NCA NAG A) and R4 (5'-NCA GCT WSC TNT SCT T) were applied [16]. Three rounds of PCR were performed using the product of each previous PCR as a template for the next. A detailed cycler program is given in Table 1.

The primary PCR was performed in a $50 \mu \mathrm{l}$ volume containing $80 \mathrm{ng}$ genomic DNA, $0.2 \mathrm{mM}$ of primers $\mathrm{S} 1$ or $\mathrm{S} 3,2 \mathrm{mM}$ of a random primer (R1, R2, R3, R4), $0.2 \mathrm{mM}$ of each dNTP and 1U Taq DNA polymerase in the appropriate buffer. The secondary PCR was performed with primers $\mathrm{M} 1$ or $\mathrm{M} 3(0.2 \mathrm{mM})$ and the same random primer $\mathrm{R}(2 \mathrm{mM})$ as used in the primary reaction. $1 \mu \mathrm{l} 1 / 50$ dilution of the primary PCR was used as a template. Singlestep annealing-extension PCR consisting of a combined annealing and extension step at 65 or $68^{\circ} \mathrm{C}$ was used in primary and secondary PCR reactions. The tertiary reaction was carried out with $1 \mu \mathrm{l}$ of $1 / 10$ dilution of the secondary reaction, $0.2 \mathrm{mM}$ primers $\mathrm{S} 1$ and $\mathrm{S} 2,0.2 \mathrm{mM}$ random primer $\mathrm{R}$ (the same as used in the previous cycles), $0.2 \mathrm{mM}$
Table 1 HE-TAIL PCR cycle settings

\begin{tabular}{|c|c|c|}
\hline Reaction & $\begin{array}{l}\text { Number of } \\
\text { cycles }\end{array}$ & Thermal settings \\
\hline \multirow[t]{4}{*}{ Primary } & 1 & $93{ }^{\circ} \mathrm{C}(1 \mathrm{~min}) ; 95^{\circ} \mathrm{C}(5 \mathrm{~min})$ \\
\hline & 5 & $\begin{array}{l}94{ }^{\circ} \mathrm{C}(30 \mathrm{~s}) ; 62^{\circ} \mathrm{C}(1 \mathrm{~min}) ; 72{ }^{\circ} \mathrm{C} \\
\quad(2 \min 30 \mathrm{~s})\end{array}$ \\
\hline & 1 & $\begin{array}{c}94{ }^{\circ} \mathrm{C}(30 \mathrm{~s}) ; 25^{\circ} \mathrm{C} \text { ramping } 72{ }^{\circ} \mathrm{C} \\
(3 \min ) ; 72{ }^{\circ} \mathrm{C}(2 \min 30 \mathrm{~s})\end{array}$ \\
\hline & 15 & $\begin{array}{l}94{ }^{\circ} \mathrm{C}(20 \mathrm{~s}) ; 65^{\circ} \mathrm{C}(3 \min 30 \mathrm{~s}) ; \\
94{ }^{\circ} \mathrm{C}(20 \mathrm{~s}) ; 65^{\circ} \mathrm{C}(3 \min 30 \mathrm{~s}) ; \\
94{ }^{\circ} \mathrm{C}(30 \mathrm{~s}) ; 42{ }^{\circ} \mathrm{C}(1 \min ) ; 72{ }^{\circ} \mathrm{C} \\
\quad(2 \min 30 \mathrm{~s})\end{array}$ \\
\hline \multirow[t]{2}{*}{ Secondary } & 1 & $72{ }^{\circ} \mathrm{C}(5 \mathrm{~min}) ; 4^{\circ} \mathrm{C}$ Hold \\
\hline & 12 & $\begin{array}{l}94{ }^{\circ} \mathrm{C}(20 \mathrm{~s}) ; 65^{\circ} \mathrm{C}(3 \min 30 \mathrm{~s}) ; \\
94{ }^{\circ} \mathrm{C}(20 \mathrm{~s}) ; 65^{\circ} \mathrm{C}(3 \min 30 \mathrm{~s}) ; \\
94{ }^{\circ} \mathrm{C}(30 \mathrm{~s}) ; 42^{\circ} \mathrm{C}(1 \min ) ; 72{ }^{\circ} \mathrm{C} \\
\quad(2 \min 30 \mathrm{~s})\end{array}$ \\
\hline \multirow[t]{3}{*}{ Tertiary } & 1 & $72{ }^{\circ} \mathrm{C}(5 \mathrm{~min}) ; 4^{\circ} \mathrm{C}$ Hold \\
\hline & 30 & $\begin{array}{l}94{ }^{\circ} \mathrm{C}(30 \mathrm{~s}) ; 42{ }^{\circ} \mathrm{C}(1 \mathrm{~min}) ; 72{ }^{\circ} \mathrm{C} \\
\quad(2 \min 30 \mathrm{~s})\end{array}$ \\
\hline & 1 & $72{ }^{\circ} \mathrm{C}(5 \mathrm{~min}) ; 4^{\circ} \mathrm{C}$ Hold \\
\hline
\end{tabular}

each dNTP, 1U DNA Taq polymerase in the appropriate buffer. To exclude nonspecific amplification, a tertiary control reaction $\mathrm{R}-\mathrm{R}$ was set up without adding genespecific primers.

\section{Amplification of gip ORF}

A PCR was used to amplify the $937 \mathrm{bp}$ ORF of the gip gene. The PCR cycling conditions were $95{ }^{\circ} \mathrm{C} / 3 \mathrm{~min}$, followed by 40 cycles of $94{ }^{\circ} \mathrm{C} / 1 \mathrm{~min}, 61{ }^{\circ} \mathrm{C} / 1 \mathrm{~min}, 72{ }^{\circ} \mathrm{C} /$ $3 \mathrm{~min}$, and ending with $72{ }^{\circ} \mathrm{C} / 10 \mathrm{~min}$. Each $25 \mu \mathrm{l}$ PCR contained $1.6 \mathrm{mM}$ dNTP, $0.2 \mathrm{mM}$ of each primer, $100 \mathrm{ng}$ genomic DNA, $1.5 \mathrm{mM} \mathrm{MgCl}_{2}$ and $0.05 \mathrm{U}$ Taq DNA polymerase in the appropriate buffer. Aliquots of the PCR reactions were separated on $0.8 \% \mathrm{w} / \mathrm{v}$ agarose gel electrophoresis and stained with ethidium bromide, to check for the presence of the expected amplicon.

\section{Bacteria transformation and DNA extraction}

Plasmids were propagated in E. coli (DH5 $\alpha$ cells), following the procedure described by [17], and plasmid DNA was extracted-purified with the Wizard ${ }^{\circledR}$ Plus SV Minipreps DNA Purification System (Promega), following the manufacturer's instructions.

Analysis of GIP production

pIM3.1 clone was harvested in LB with kanamicin and protein expression was induced by adding $1 \mathrm{mM}$ IPTG at $0,2,4,6$ and $8 \mathrm{~h}$ of growth. Secreted proteins were 
concentrated by precipitation with trichloroacetic acid (TCA $8 \% \mathrm{v} / \mathrm{v}$ ), from the supernatant and with a lysis solution $(50 \mathrm{mM}$ Tris-HCl pH 7.5, $50 \mathrm{mM}$ EDTA e $1 \mathrm{mM}$ PMSF) from $E$. coli cells.

Protein quantification was performed by using the Protein quantification kit-general use (Fluka), following the manufacturer's instructions. After quantification, secreted proteins at all induction time points $(0,2,4,6$ and $8 \mathrm{~h})$ were separated by SDS-PAGE $(15 \% \mathrm{w} / \mathrm{v})$. The membrane was stained with Coomassie brilliant blue BG-250 $0.25 \%$ (BioRad), and then was washed in a solution of methanol $45 \%(\mathrm{v} / \mathrm{v})$ and acetic acid $10 \%(\mathrm{v} / \mathrm{v})$.

\section{Expression of gip gene}

A Real-Time Quantitative PCR (RT-qPCR) assay was performed in order to analyze gene expression in vitro and in vivo.

\section{In vitro}

P. cinnamomi was grown in different carbon sources $(2 \%$ $(\mathrm{w} / \mathrm{v})$ glucose, $0.2 \%(\mathrm{w} / \mathrm{v})$ cellulose and $0.2 \%(\mathrm{w} / \mathrm{v})$ sawdust) and the expression of gip gene was evaluated at 2, 4, 6 and 8 days of growth. Control cells were grown in dextrosecontaining medium (PDA). The expression level of the gip gene was expressed relative to the expression level of the housekeeping gene actin2, measured at 4 different times of induction with glucose, cellulose and sawdust.

\section{In vivo}

C. sativa roots were covered with fully colonized PDA and incubated in the dark at $25^{\circ} \mathrm{C}$ for 12,24 and $36 \mathrm{~h}$. Negative controls were provided by roots in contact with non-colonized agar. After the incubation period, the agar was removed, along with all external mycelia growth. The roots were examined for the presence and extent of necrosis and then frozen to $-80{ }^{\circ} \mathrm{C}$. The assays were repeated three times. The expression level of the gip gene was expressed relative to the level measured in the reference gene actin2. Results were normalized to actin 2 gene and calculated using the $2^{-\Delta \Delta \mathrm{Ct}}$ method, as fold change relative to control cells.

Total RNA was isolated from $P$. cinnamomi mycelia using the Rneasy Plant Mini Kit (Qiagen), following the manufacturer's instructions. Residual DNA was removed by DNase I (Qiagen) treatment, following the manufacturer's instructions. The integrity of the RNA was assessed by formaldehyde agarose gel electrophoresis (1.5\% agarose). $1 \mu \mathrm{g}$ of RNA was reverse transcribed the iScript $^{\mathrm{TM}}$ cDNA Synthesis Kit (BioRad) primed with oligo (dT), following the manufacturer's instructions. The qPCR was performed with $\mathrm{IQ}^{\mathrm{TM}} \mathrm{SYBR}^{\circledR}$ Green Supermix (Biorad) Real Time using a MiniOpticon ${ }^{\mathrm{TM}}$ Real-Time PCR Detection System (Biorad). Each $25 \mu \mathrm{l}$ reaction contained $100 \mathrm{ng}$ RNA, as well as $12.5 \mu \mathrm{l}$ IQ SYBR Green Supermix (100 mM KCl, $40 \mathrm{mM}$ Tris- $\mathrm{HCl} \mathrm{pH} 8.4,0.4 \mathrm{mM}$ of each dNTP, $50 \mathrm{U} / \mathrm{ml}$ iTaq DNA polymerase, $6 \mathrm{mM} \mathrm{MgCl}_{2}, 20$ nM SYBR Green I fluorescein, and stabilizers) and $1.25 \mu \mathrm{M}$ of each primer. The reactions were run in triplicate and incubated at $95{ }^{\circ} \mathrm{C}$ for $3 \mathrm{~min}$, followed by 40 cycles of $95{ }^{\circ} \mathrm{C} / 30 \mathrm{~s}, 61{ }^{\circ} \mathrm{C} / 30 \mathrm{~s}$ and $72{ }^{\circ} \mathrm{C} / 30 \mathrm{~s}$. The endogenous control was normalized to the expression levels of actin2 gene within the same sample. Amplification primers (Table 2) were targeted to the coding regions of $P$. cinnamomi actin2 and gip genes.

\section{Southern blot analysis}

Genomic DNA of P. cinnamomi strain PR120 was isolated as described above. $12 \mu \mathrm{g}$ of DNA was digested with ApaI, $X h o \mathrm{I}-\mathrm{ClaI}$ and EcoRI restriction enzymes and size-separated by electrophoresis on a $1 \%$ agarose gel. DNA was blotted onto a Hybond- $\mathrm{N}^{+}$membrane (Amersham) by capillary transfer [18], and hybridized at high stringency at $65^{\circ} \mathrm{C}$, following the instructions for DIG Wash and Block Buffer Set (Roche Diagnostics, Basel, Switzerland).

DIG-labeled probes were generated by PCR using the primers SacGIP and HindGIP described above which amplify an ORF 937 bp fragment of the gip gene, following the protocol of the PCR DIG Probe Synthesis Kit (Roche Diagnostics, Basel, Switzerland). Blots were washed twice in $2 \times \mathrm{SSC}$ and $0.5 \%$ SDS at room temperature for $5 \mathrm{~min}$, and subsequently washed twice in $0.5 \times$ SSC and $0.5 \%$ SDS at $65{ }^{\circ} \mathrm{C}$ for 15 min. Detection was performed at room temperature following the instructions for DIG Wash and Block Buffer Set (Roche Diagnostics).

\section{Results and discussion}

This work reports the sequencing, using the HE-TAIL PCR [16] of a class of GIPs, that are secreted by P. cinnamomi and that specifically inhibit the endoglucanase activity of

Table 2 Sequences of primers used to amplify actin2 and gip genes in the RT-qPCR experiments

\begin{tabular}{lll}
\hline Target gene & Forward primer sequence $\left(5^{\prime} \rightarrow 3^{\prime}\right)$ & Reverse primer sequence $\left(5^{\prime} \rightarrow 3^{\prime}\right)$ \\
\hline actin2 & GGCCTCGAGAAGAGCTACG & CTTCATGATGGTCTGGAACG \\
gip & TGGTGGTGCTCTCATCAGTC & GCGAACTTGCTTGGATTCTC \\
\hline
\end{tabular}


their plant host, thereby suppressing the degradation of glucans in the oomycete cell wall and the release of oligoglucoside elicitors.

We obtained a small sequence of 308 bp by amplification using degenerated primers designed based on homology in the open reading frames of other GIPs ( $P$. sojae), and the full length gene sequence $(1301 \mathrm{bp})$ was obtained by flanking the known sequence with asymmetric PCR. gip Gene encodes a 312 aa protein that shares significant structural similarity with the chymotrypsin class of serine proteases (SP), but lack proteolytic activity due to the absence of an intact catalytic triad (His-Asp-Ser) and, thus, belong to a broader class of proteins called serine protease homologs (SPH).

GIPs show high homology with the S1A subfamily of SP; however questions remain about the expression patterns and potential roles of different GIPs during pathogenesis and their possible interaction with host EGases in the plant apoplast. In order to understand gene function, we analyzed gene expression during growth in different carbon sources and also performed a time course of gip expression by RT-qPCR procedure. The ORF (937 bp) of gip gene was cloned into a different expression plasmid in order to perform the analysis of heterologous expression, in E. coli.

FAST alignments revealed significant homologies (60-84\%) of the GIP sequence of $P$. cinnamomi with sequences of $P$. sojae and $P$. infestans including regulatory sequences as trypsin-like SP. Many of these are synthesized by the precursor inactive zymogens and are cleaved during their limited proteolysis to generate active forms [14].

Amplification and characterization of the gip gene of $P$. cinnamomi

Starting with the amplification of a small $308 \mathrm{bp}$ fragment of the gip gene obtained from P. cinnamomi strain 120 DNA, the application of the HE-TAIL PCR method led to the successful amplification of the entire sequence of the gene (GenBank: AM259384.1) with a total length of $1301 \mathrm{bp}$ and a $937 \mathrm{bp}$ ORF which encodes a 312 aa protein.

The genus Phytophthora is one of only a few eukaryotic genera for which at least three complete genome sequences are available, thereby allowing an unusually broad view of gene family evolution. The phylogeny provides eight examples of genes represented by at least one ortholog in each of the three species and two other cases in which an ortholog appears to have been duplicated, lost, or both in one of the three species. Examples include both GIPs (for example, GIP1 has a full set of orthologs and paralogs while GIP2 has orthologs but no paralogs) and apparently functional SP, such as PiSP1, which has a full set of orthologs. It is estimated that there are at least five GIPrelated SP and at least five GIP-related SPH prior to the diversification of Phytophthora spp. The gene organization

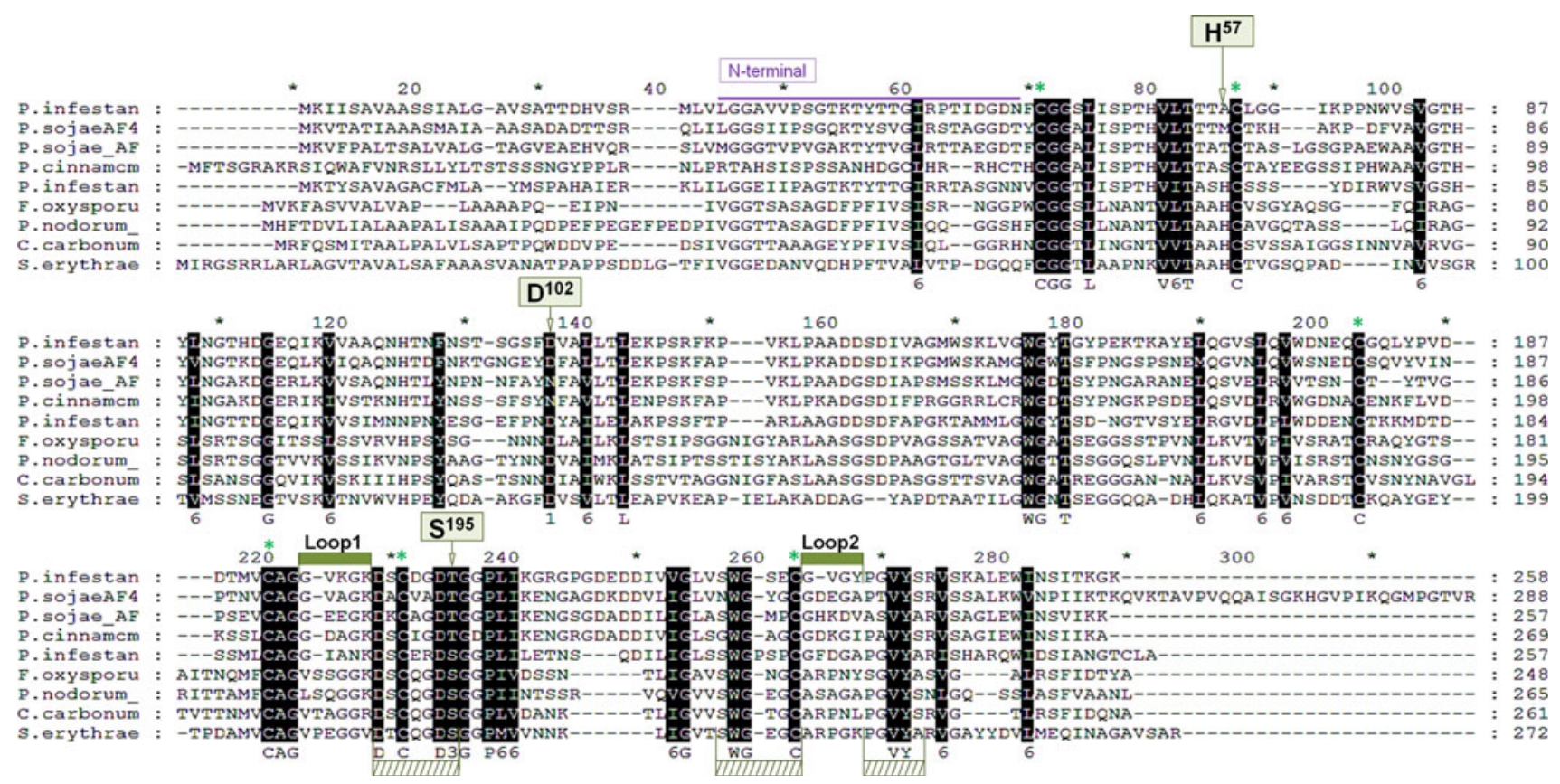

Fig. 1 Sequence alignment of GIP proteins and Ser Proteases. The N-terminal signal sequence is indicated by a horizontal bar. Conserved Cys residues involved in disulfide bond formation are indicated by asterisks. The position of the His57, Asp102, and Ser195 residues of the catalytic triad are indicated with arrows. Sites that are predicted to form SP surface loops 1 and 2 are boxed, and residues forming the walls of the substrate binding pocket are underlined boxes 
of GIPs, SPH, and SP was assessed by searching their respective locations in each of the genome sequences. For all three species, the GIP genes and some of the GIP-like genes were clustered in a scaffold, or supercontig, while the remaining genes were distributed among other supercontigs [19].

A BLAST search of the databases revealed that the GIPs protein sequences are homologous with the chymotrypsin subclass of SP. The overall amino acid sequence homology of the GIPs with a number of chymotrypsins was similar to that typically observed among SP $(\sim 20-40 \%)$, and a number of characteristics features of SP were also present, including many sequence motifs and six cysteine residues (Fig. 1). A characteristic feature of SP is the catalytic triad charge relay system, referred to as His-57, Asp-102, and Ser-195 that are essential for the proteolytic function. However, interestingly none of the predicted GIPs possess this intact "catalytic triad" [14]. Therefore, while GIPs strongly resemble SP, they are not expected to function as proteases. The triad of $P$. cinnamomi GIP is Ser-57, Asn102 and Thr- 195.

Although GIPs are proteolytically inactive, several stretches of amino acids and motifs that are highly conserved among SP, are present in the GIPs. Firstly, an $\mathrm{N}$-terminal signal sequence is present that targets the enzyme for secretion. Secondly, the GIPs possess three characteristically spaced pairs of Cys residues that are involved in the formation of disulfide bonds. Thirdly, key functional residues are present in the S1A specific substrate binding pocket and the two regions that flank the catalytic residues in the binding pocket form so-called variable surface loops 1 and 2 . These surface loops contribute to the geometry of the SP specificity pocket and act synergistically to influence selective substrate binding and catalysis.A phylogenetic analysis of the GIP sequences aligned with other S1A clan SP from a number of evolutionarily diverse organisms revealed that the GIPs form a distinct group.

The substantial amount of literature related to SP structure and function provides a valuable opportunity to make structural predictions about GIPs and to identify regions of the proteins that are involved in binding to the $\alpha$ endoglucanases ligands or that may dictate ligand specificity (Fig. 2).

The overall geometry of the two classes of proteins is clearly predicted to be very similar and the software analysis designated the structure as a high confidence prediction. The model in Fig. 5c assumes that the inhibitor uses a trypsin-like mechanism of recognition [20] whereby GIP identifies a Lys residue on the surface of the glucanase molecule.

GIPs represent the first example of proteolytically inactive SP homologs that function as enzyme inhibitors. It can be hypothesized that a major role for GIP is to suppress the release of glucan elicitors during $P$. cinnamomi infection, thereby reducing the effectiveness of the plant host's surveillance system [19, 21].

\section{Protein production assay}

The expression of the gip gene of $P$. cinnamomi was induced in $E$. coli transformed with the plasmid pIM3.1 resulting from the insertion of the 937 bp gip ORF in the plasmid pET28a(+). The aim of this assay was to study the gip gene in a heterologous organism, E. coli in our case. For that have we used the pET-28a(+) expression system to clone the gene into the bacteria.

The band corresponding apparently to the $31 \mathrm{kDa}$ GIP protein is shown with the arrow, $8 \mathrm{~h}$ after induction (Fig. 3).

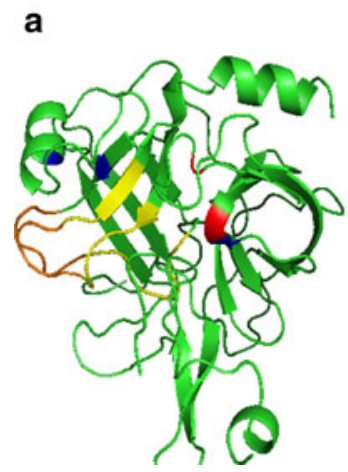

Fig. 2 a The crystal structure of R117 H mutant rat anionic trypsin complexed with bovine pancreatic trypsin inhibitor BPTI (PDB 1C07) was used as a template to predict the corresponding structure of $P$. cinnamomi GIP; in b using a computational approach (ESyPred3D). The catalytic triad of trypsin and the equivalent residues of GIP are b

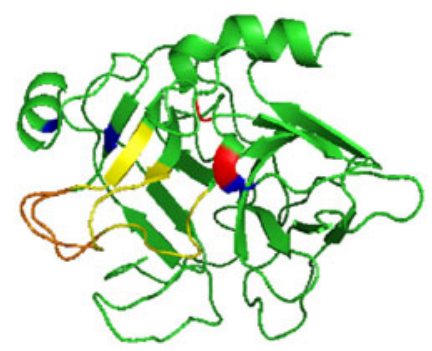

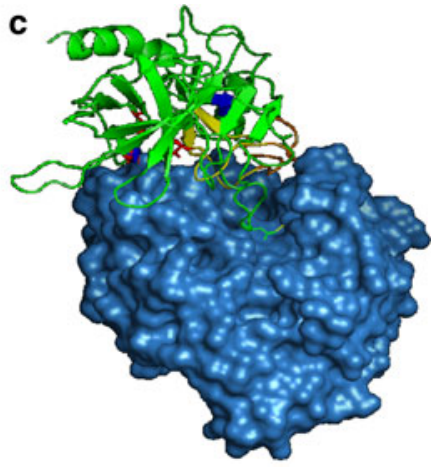

colored. Red catalytic triad, blue conserved Cys residues, yellow residues forming the walls of the substrate binding pocket, orange amino acids predicted to form surface loops1 and 2; c A model of an $\beta$-endoglucanase (PDB 1AQ0) docking with $P$. cinnamomi GIP 


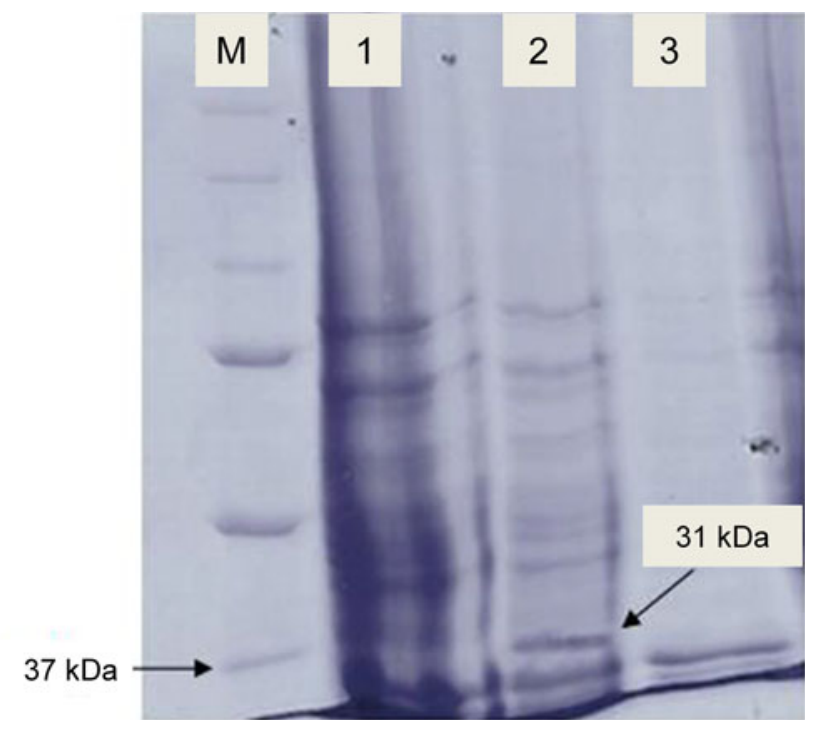

Fig. 3 Separation of the expressed GIP protein in a polyacrylamide/ SDS gel $(15 \%)$ at $8 \mathrm{~h}$ following induction. $M$ precision plus protein marker; 1,3 E. coli no induction; 2 GIP induction. (Color figure online)

\section{Infection of C. sativa roots}

Infection of the host roots was performed with mycelium of the $P$. cinnamomi isolate Pr120. The first necrotic lesions appeared after about $12 \mathrm{~h}$, in those areas in direct contact with the inoculum. By $24 \mathrm{~h}$, the original lesions had extended along the root. By $36 \mathrm{~h}$ post-inoculation, the root necrosis had spread, and was localized in the non-suberized region of the root (Fig. 4).

\section{Quantification of gip transcripts}

The expression of gip gene in response to glucose, cellulose and sawdust was studied in $P$. cinnamomi cells using primers specific to this gene. The expression levels of actin2 gene were used as internal cDNA loading controls [22].

Mycelia of $P$. cinnamomi were incubated either with glucose $2 \%(\mathrm{w} / \mathrm{v})$, cellulose $0.2 \%(\mathrm{w} / \mathrm{v})$ or sawdust $0.2 \%$ (w/v), for 2, 4, 6 and 8 days. Those three substrates were chosen considering the plant-pathogen system. The choice of actin mRNA as a stable endogenous control to normalize the amount of sample RNA was validated by evaluation of the oomycete actin mRNA levels in in vitro and in planta conditions. In RNA extracted from various in vitro cultures both bands (18S and 28S), had identical intensity, showing that an identical quantity of Phytophthora RNA was present, the intensity of actin mRNA bands was similar in all samples, showing that actin mRNA levels were also identical [23].

Total RNA was extracted from these cells, cDNA was synthesized and gene expression measured by qRT-PCR.

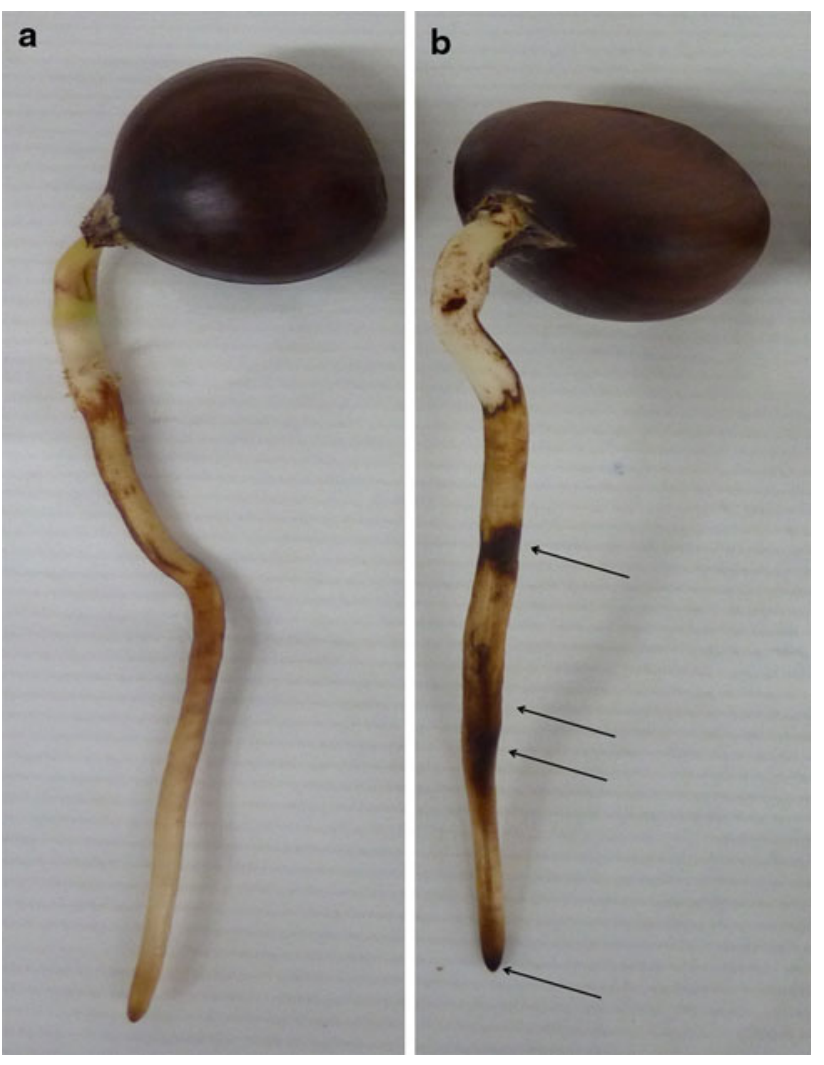

Fig. 4 Necrotic effect of $P$. cinnamomi in $C$. sativa roots. $C$. sativa roots were covered by fully colonized V8 agar and incubated for $24 \mathrm{~h}$ in the dark at $25^{\circ} \mathrm{C}$. Necrotic tissue is indicated by arrows. a Control, non infected root; b Infected root

The results were normalized to actin2 gene and calculated as fold change relative to control cells.

Analysis of the expression levels of the gip gene in mycelia of $P$. cinnamomi grown in glucose, cellulose and sawdust for 2, 4, 6 and 8 days shows that different carbon sources induce a small increase in the expression levels of gip gene from 2 to 4 days. A higher increase is observed after 6 and 8 days (Fig. 5). The gene expression level in sawdust tends to be higher than in glucose and in cellulose with increasing culture age.

The type of medium had a visible effect on the level of expression of the gip gene-it is significantly higher in sawdust than in glucose or cellulose and incremented in all media as the culture aged. This fact may be related with the adaptation of the pathogen at the culture media. Also, both glucose and cellulose are simple carbon sources compared with sawdust; thus, are easily degraded by the pathogen. In this work, sawdust is the substrate that present more similarity with the natural substrate used by the pathogen and protein expression is definitely related with this fact.

The expression levels of gip transcripts in planta, after infection of $C$. sativa roots, analyzed at different times, are represented in Fig. 6. Expression significantly increases from 12 to $24 \mathrm{~h}$ and then significantly decreases at $36 \mathrm{~h}$. 


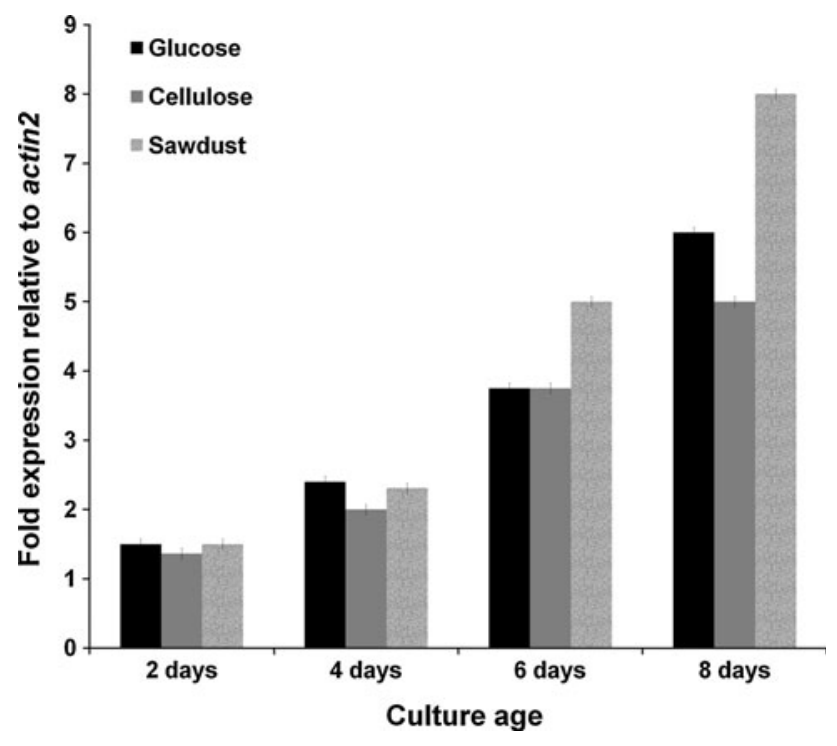

Fig. 5 Effect of glucose, cellulose and sawdust on the expression levels of the gip gene of $P$. cinnamomi. Mycelia of the wild type Pr120 isolate were exposed to glucose $2 \%(\mathrm{w} / \mathrm{v})$, cellulose $0,2 \%$ (w/ v) and sawdust $0,2 \%(\mathrm{w} / \mathrm{v})$ for 2, 4, 6 and 8 days. RNA was isolated from these cells, cDNA was synthesized and the expression levels of the gip gene were analyzed by qRT-PCR, using specific primers. Values were normalized to the expression levels of actin 2 gene determined in the same sample and are shown as relative mean values \pm standard deviation (SD) of 3 experiments done in triplicate

The expression values are generally lower than those found in growth media with different carbon sources (Fig. 5), which could be explained by an inhibitory factor secreted by the plant. Because GIPs are secreted by $P$. cinnamomi in the absence of the host plant, we do not observe as many variations of this protein expression as we observe in the presence of different carbon sources during infection (Fig. 5). This fact verifies the host-pathogens interactions in planta. This oscillation in values of expression during infection also suggests a complex mechanism of interaction involving the pathogen and a defensive response [14].

In planta results show that, for a pathogen to colonize a host successfully, it must develop mechanisms to evade detection or, failing that, to subvert defense responses. Models have been proposed in which pathogen-derived effector molecules, interfere with elicitor binding, signal transduction, gene activation, or the activities of the defense responses [2, 24].

The ability of plants to quickly and accurately perceive their biotic attackers is essential for mounting an effective defense. Plants must identify and respond to the chemical effectors and mechanical signals that accompany the attack. A number of structurally diverse "suppressors" have been identified that constrain active resistance in plants [25]. They are considered to be determinants of pathogenicity and are defined as factors that are produced at the infection site, participate in suppressing general

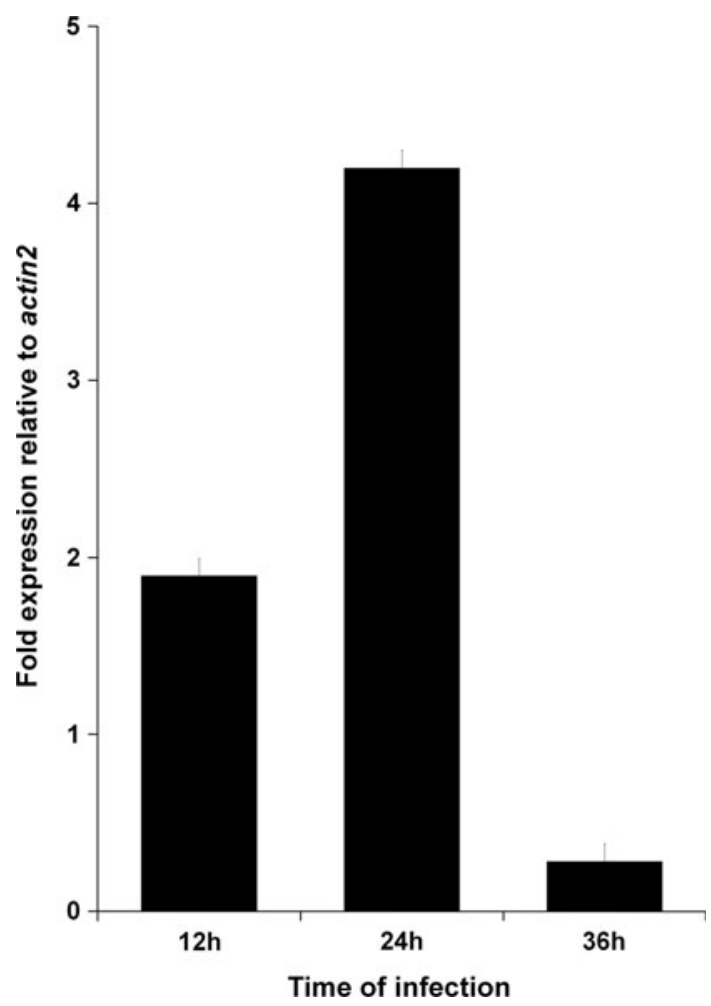

Fig. 6 Expression levels of the gip gene in $P$. cinnamomi during infection of $C$. sativa roots. $C$. sativa roots were exposed to mycelia of the wild type isolate Pr120 for 12, 24 and $36 \mathrm{~h}$. RNA was isolated from these cells, cDNA was synthesized and the expression levels of the gip gene were analyzed by qRT-PCR, using specific primers. Values were normalized to the expression levels of actin2 gene determined in the same sample and are shown as relative mean values \pm standard deviation (SD) of 3 experiments done in triplicate

resistance, induce local susceptibility and that are not toxic to plants. Certain glycoproteins and glucans have been classified as suppressors (for a review, see [25]) and additional studies may reveal that GIPs also should be classified as suppressors. Unlike GIPs, none of the currently defined suppressor molecules has been shown to inhibit the generation of elicitors as well as the activity of a downstream defense response [14].

\section{Southern blot analysis}

Southern blot analysis of $P$. cinnamomi genomic DNA was performed to determine the existence of GIP homologous sequences. ApaI (which cuts at positions 26 and 1099), XhoI-ClaI (which cuts at positions 397 and 1019) and EcoRI (that does not cut in this sequence), restriction enzymes were used to digest the DNA.

The digestion with ApaI reveals a unique band corresponding to an expected $1073 \mathrm{bp}$ fragment (Fig. 7, lane 1). However, the double digestion with the enzymes XhoI-ClaI (Fig. 7, lane 2) not only reveals the expected 622 bp band but also two more bands, longer than $1500 \mathrm{bp}$, suggesting 


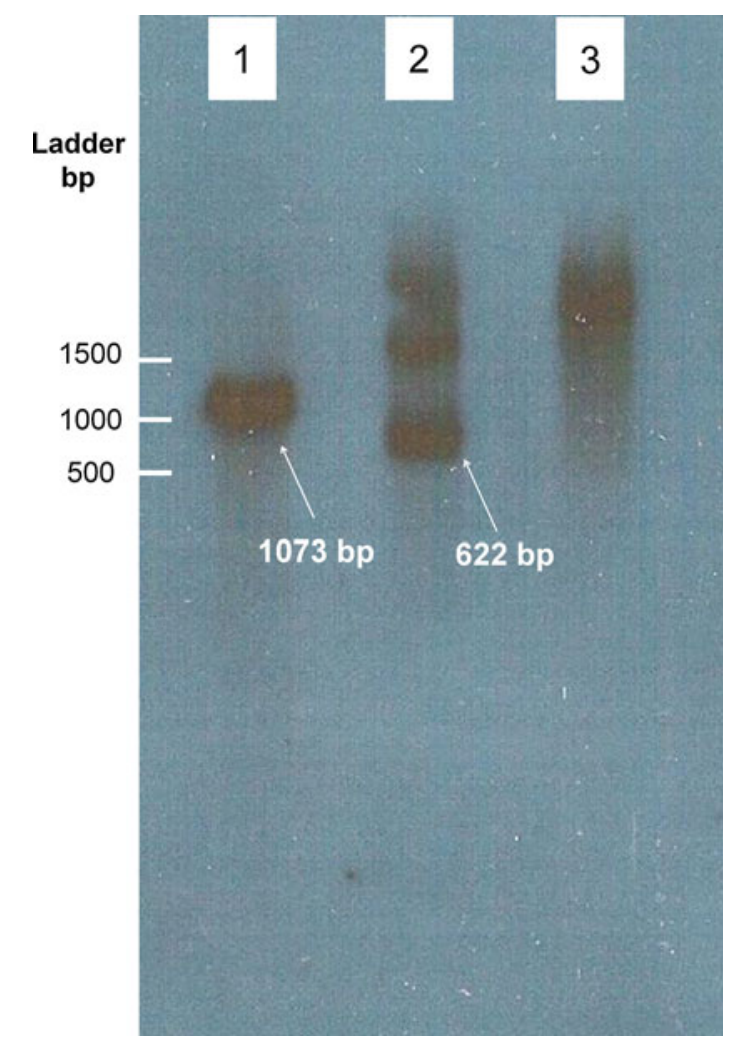

Fig. 7 Southern blot hybridization using a DIG-labeled 937 bp long PCR-generated probe representing the ORF of $P$. cinnamomi gip gene. Genomic DNA was digested with ApaI (1), XhoI/ClaI (2) and EcoRI (3)

the possible existence of gip paralogs in P. cinnamomi. Despite the assessment of the double digestion efficiency, it is possible that the two bands longer than $1500 \mathrm{bp}$ observed with the XhoI-ClaI enzymes could be partial digestions. The observation of a band larger than $1500 \mathrm{bp}$ upon digestion with EcoRI shows that this enzyme cuts at restriction points flanking this gene (Fig. 7, lane 3).

This observation of GIP homologues in species of the Phytophthora genus has previously been documented. The phylogeny provides eight examples of genes represented by at least one ortholog in each of the three species and two other cases in which an ortholog appears to have been duplicated, lost, or both in one of the three species. Examples include both GIPs (GIPl has a full set of orthologs and paralogs while GIP2 has orthologs but no paralogs) and apparently functional SP, such as PiSPI, which has a full set of orthologs [19].

In conclusion, HE-TAIL PCR is an efficient method to amplify unknown genomic DNA sequences adjacent to short known regions. This technique made possible to sequence $P$. cinnamomi gip gene that showed sequence homology with serine-proteases, and possessed a number of conserved sequence motifs, a similar geometric arrangement of the catalytic residues and a common reaction mechanism.
Acknowledgments This work was financially supported by the EC III Framework Programme for Research and Technological Development, co-financed by the European Social Fund (ESF) and by national funding from the Portuguese Ministério da Ciência e do Ensino Superior (MCES) (PTDC/AGR-AAM/67628/2006).

\section{References}

1. Erwin DC, Ribeiro OK (1996) Phytophthora diseases worldwide. American Phytopathological Society Press, St. Paul

2. Knogge W (1998) Fungal pathogenicity. Curr Opin Plant Biol 1(4):324-328

3. Hardham AR (2005) Phytophthora cinnamomi. Mol Plant Pathol 6(6):589-604

4. King M, Reeve W, Van der Hoek MB, Williams N, McComb J, O'Brien PA, Hardy GE (2010) Defining the phosphite-regulated transcriptome of the plant pathogen Phytophthora cinnamomi. Mol Genet Genomics 284(6):425-435

5. Birch PR, Rehmany AP, Pritchard L, Kamoun S, Beynon JL (2006) Trafficking arms: oomycete effectors enter host plant cells. Trends Microbiol 14(1):8-11

6. Ellis J, Catanzariti AM, Dodds P (2006) The problem of how fungal and oomycete avirulence proteins enter plant cells. Trends Plant Sci 11(2):61-63

7. Kamoun S (2007) Groovy times: filamentous pathogen effectors revealed. Curr Opin Plant Biol 10(4):358-365

8. Schornack S, Huitema E, Cano LM, Bozkurt TO, Oliva R, Van Damme M, Schwizer S, Raffaele S, Chaparro-Garcia A, Farrer R, Segretin ME, Bos J, Haas BJ, Zody MC, Nusbaum C, Win J, Thines M, Kamoun S (2009) Ten things to know about oomycete effectors. Mol Plant Pathol 10(6):795-803

9. Kamoun S (2003) Molecular genetics of pathogenic oomycetes. Eukaryot Cell 2(2):191-199

10. Attard A, Gourgues M, Galiana E, Panabieres F, Ponchet M, Keller H (2008) Strategies of attack and defense in plant-oomycete interactions, accentuated for Phytophthora parasitica Dastur (syn. P. Nicotianae Breda de Haan). J Plant Physiol 165(1): 83-94

11. Day B, Graham T (2007) The plant host pathogen interface: cell wall and membrane dynamics of pathogen-induced responses. Ann N Y Acad Sci 1113:123-134

12. Kamoun S, Huitema E, Vleeshouwers VG (1999) Resistance to oomycetes: a general role for the hypersensitive response? Trends Plant Sci 4(5): 196-200

13. Valueva TA, Mosolov VV (2004) Role of inhibitors of proteolytic enzymes in plant defense against phytopathogenic microorganisms. Biochemistry (Mosc) 69(11):1305-1309

14. Rose JK, Ham KS, Darvill AG, Albersheim P (2002) Molecular cloning and characterization of glucanase inhibitor proteins: coevolution of a counterdefense mechanism by plant pathogens. Plant Cell 14(6):1329-1345

15. Raeder U, Broda P (1985) Rapid preparation of DNA from filamentous fungi. Lett Appl Microbiol 1(1):17-20

16. Michiels MT, Van den Ende W, Van Laere A (2003) Chromosomal walking of flanking regions from short known sequences in GC-rich plant genomic DNA. Plant Mol Biol Rep 21:295-302

17. Hanahan D (1983) Studies on transformation of Escherichia coli with plasmids. J Mol Biol 166(4):557-580

18. Sambrook J, Fritsch EF, Maniatis T (1989) Molecular cloning: a laboratory manual, 2nd edn. Cold Spring Harbor Laboratory Press, Cold Spring Harbor

19. Damasceno CM, Bishop JG, Ripoll DR, Win J, Kamoun S, Rose JK (2008) Structure of the glucanase inhibitor protein (GIP) family from Phytophthora species suggests coevolution with 
plant endo-beta-1,3-glucanases. Mol Plant Microbe Interact 21(6):820-830

20. York WS, Qin Q, Rose JK (2004) Proteinaceous inhibitors of endo-beta-glucanases. Biochim Biophys Acta 1696(2):223-233

21. Liu B, Xue X, Cui S, Zhang X, Han Q, Zhu L, Liang X, Wang X, Huang L, Chen X, Kang Z (2010) Cloning and characterization of a wheat beta-1,3-glucanase gene induced by the stripe rust pathogen Puccinia striiformis f. sp. tritici. Mol Biol Rep 37(2):1045-1052

22. Murfett J, Wang XJ, Hagen G, Guilfoyle TJ (2001) Identification of Arabidopsis histone deacetylase HDA6 mutants that affect transgene expression. Plant Cell 13(5):1047-1061
23. Horta M, Sousa N, Coelho AC, Neves D, Cravador A (2009) In vitro and in vivo quantification of elicitin expression in Phytophthora cinnamomi. Physiol Mol Plant P 73:48-57

24. Staskawicz BJ (2001) Genetics of plant-pathogen interactions specifying plant disease resistance. Plant Physiol 125(1):73-76

25. Shiraishi T, Yamada T, Ichinose Y, Kiba A, Toyoda K (1997) The role of suppressors in determining host-parasite specificities in plant cells. Int Rev Cytol 172:55-93 